UDK: 37.091.313-026.15

Practical experience

\title{
CREATIVE PROJECTS IN EDUCATION (EXPERIENTIAL PRACTICE AND SUGGESTIONS FOR YOUNGER TEACHERS, IN PARTICULAR)
}

Adriana Beletić

Faculty of Educational Sciences, Department of Engineering Juraj Dobrila University of Pula Republic of Croatia adriana.beletic@yahoo.com 


\section{ABSTRACT}

Creativity is considered the ability to go beyond established patterns or rules and see outside the box. It has become an indispensable quality in the fast-changing world of today, being it connected with an enterprise, a relationship or an education likewise. The creative urge is an innate quality, which, nevertheless, needs to be nurtured and practised both at home and/or educational institutions at as early an age as possible. The aim of this paper is to offer just a small number of ideas and suggestions, compared to the innumerable creative possibilities that all learners and educators (may) have. After the initial spark has been ignited, leave the rest to the inner creative power.

Keywords: transcending patterns, (subjective) visualization, new approaches, freedom, suggestions for creative responses, pop-up books, creativity killers. 


\section{INTRODUCTION}

According to some dictionaries and paraphrased, creativity is the ability to transcend established patterns and visualize, create and use new ideas to improve all segments of life including the animal world, nature and the universe itself. It is the heart of progress which can apply to a recipe, a business, a piece of art, philosophy, science, industry, quality of life or a nursery rhyme.

Parents are, or should be, the first role models for their children's behaviour, including the creativity sparkle which, if not instigated, should at least not be suppressed. No matter how weird it might seem, a child's first creation are his feces (Clarkson, NLP in the theatre, Pula workshop, 2004) and it is of utter importance parents react positively should they witness their child admiring their body makings. The parents' reactions will leave a deep footprint on the children's subconscious mind which will affect their future responses to creative tasks or creativity in general.

Likewise, nursery and kindergarten teachers should be aware of the impact their attitude and responses have on a child's emotional, intellectual and social development. During consequent educational stages and concerning other subject matters than the one cited earlier, educators should restrain from imposing their personal, subjective visions and beliefs onto a child's vision. Let us, educators, allow children their right to be individuals and enjoy their own creativity, inventiveness, originality, ingenuity, resourcefulness, and life. It is their (as well as our) sacred claim as human beings.

Scientific, natural, linguistic, art and other theories, facts, laws and rules (which are nevertheless liable to change) are still taught, explained, demonstrated and put into practice, at the same time allowing students the freedom to express the above facts and laws in their own way. In this respect, educators should have a background role and help with their expertise, suggestions, support and love. Strictness, restrictions and repression have proved to stifle creativity. On the other hand, all successful and extraordinary figures in the history of mankind have proved that what pays off are the stubbornness and persistence to follow one's own visions and dreams, and the courage to see outside the box.

Nowadays, the importance of creativity, flexibility and the ability to react freely and multivisionally to the challenges of life have been recognized as valuable and indispensable characteristics that are necessary, expected and welcome in a business or domestic situation likewise (Osho, 2017). Therefore, the sooner we start nourishing these virtues, both in the family and institutions, the better. 


\section{SUGGESTIONS, IN NO PARTICULAR ORDER}

To a certain extent, the following experiential suggestions can be applied to all school subjects and may be used in all lesson stages or for long-time projects. Teachers may also give more than one option, bearing in mind to include all types of learners. The ideas are:

- expressing the subject matter through drawings and colouring or pictures

- transforming the theme into a radio / TV news / newspaper / magazine report (students may choose the type of audience they are addressing)

- creating a comic book

- preparing interview questions (and using them in a survey)

- making up a dialogue between two people covering the targeted topic (teachers can request the inclusion of some words or phrases)

- individual, pair or group recording, and sharing them with another student or group

- finding the most unusual possibilities to use the item(s) being taught or studied

- writing a convincing text on why something should be used, tried, owned, visited, etc., followed by an oral heartfelt presentation (students may use some kind of disguise to feel more comfortable)

- writing simplified instructions for making, (re)using, obtaining or developing something

- writing and drawing extremely detailed instructions for aliens, i.e. for somebody who has never seen or used an object before

- finding and drawing/photographing/filming objects, shapes, plants, colours, rocks, etc. in an area

- visualizing the steps an inventor went through before reaching the final result

- turning a subject into a haiku poem (Sample 1), a free verse poem or a poem following a rhymed scheme. 


\section{Sample 1. Haiku poems}

Language,

Different, interesting

Learning, building, understanding

Subconsciously learning a foreign language.

Fun.

\section{School,}

Spontaneous, confident

Learning, making, relaxing

The results are amazing

Learners

- writing some song lyrics according to the original syllable scheme; Examples:

a) pronunciation of the Past Simple ending -ed (Original song Are You Sleeping, Brother John.);

Noticed, reeeaaached and addreeeessed Travelled, followed, formed, complained pushed and liiiiked, liked and puuushed Disappeared, realized Stopped and looked and aaaasked Managed, loved, continued Stopped and looked and aaaasked Called, arrived, died, answered Pushed, reached, liked. Tried, pulled, tuuurned, Pushed, reached, liked Tried, pulled, tuuurned

/id/

Wanted, started, wounded, knighted

Shouted too, shouted too

Knighted and succeeded

Knighted and succeeded

De-par-ted, de-par-ted

b) dolphins and echolocation (Original song The Itsy Bitsy Spider.).

These clicks and squeaks and whistles

Are used to talk and spot

Echolocation, and

Dolphins know where's what

Out they emit, and

When the echo's back

They surely can locate friends,

Their pod and fish and boat; 
- using acronyms and acrostics to remember better

- students becoming experts and teaching peers (one at a time and repeating 3-4 times to other students)

- keeping personal Journals or Scrapbooks using all or some of the above completed tasks

- creating a class project (pop-up) book using all students' completed tasks. See the explanations and tables below for the class project This Is My School (Students of the Faculty of Educational Sciences in Pula: Batelić Karla, Burić Sara, Floričić Stefani, Klarić Sunčica, Mufić Ivana, Jakičić Adriana, Jelić Edi, Juranović Vesna, Peršić Ivana).

\section{Pop-up books}

Pop-up books are effective, fun and easy to create, and the results are rewarding. The steps can be followed on the web site mentioned above, or, simplified, they are:

1 - Write your text or draw something connected with your project on a paper slip, best if $6 \times 6 \mathrm{~cm}$, but you can choose another size or shape.

2 - Get some A4 papers: 1 for each student plus 1 coloured paper for the cover.

3 - Each student gets 1 A4 paper and decides about the number of pop-up slips they are going to insert.

4 - Fold the sheet of paper across.

5 - Mark the paper $5+2.5+6+2.5+5 \mathrm{cms}$ for 2 tabs that are $5 \mathrm{cms}$ long; for 1 pop-up, you decide where you will place the $2.5 \times 5 \mathrm{cms}$ long tab.

6 - Cut the two 5 centimeters long lines to get 1 tab; repeat if there are more tabs.

7 - Open the paper, push the tab(s) forward and press the edges.

8 - Glue the text(s) / drawing(s) on the tab(s).

9 - Next to the text(s) / drawing(s), write or draw about your project.

10 - Put all the students' pages together in the agreed and desired order.

11 - Glue all the pages without the drawings/texts/pictures back to back.

12 - Let the book dry.

13 - Make the cover page.

14 - At the back you may write the place, date, etc.

15 - Glue the cover and cut the extra paper on the right edge.

16 - Let dry.

17 - Enjoy your Project Pop-Up Book 
The steps in the project This Is My School ${ }^{1}$ were as follows:

a. The students explored the Austro-Hungarian building looking for some (intriguing) details.

b. They took some pictures.

c. The photos were used to draw their own vision of the detail(s).

d. They wrote their own (his)stories in connection with the drawings/ details.

e. Each student created one pop-up page (Photograph 1).

f. The pages were glued together (Photograph 2).
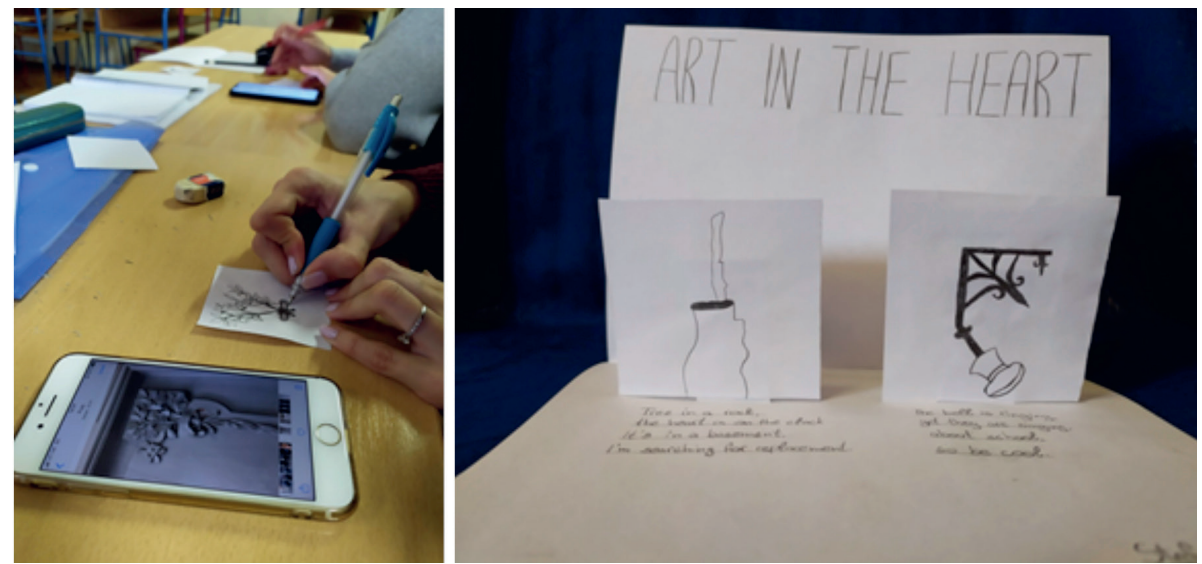

Photograph 1. Students' pop-up pages

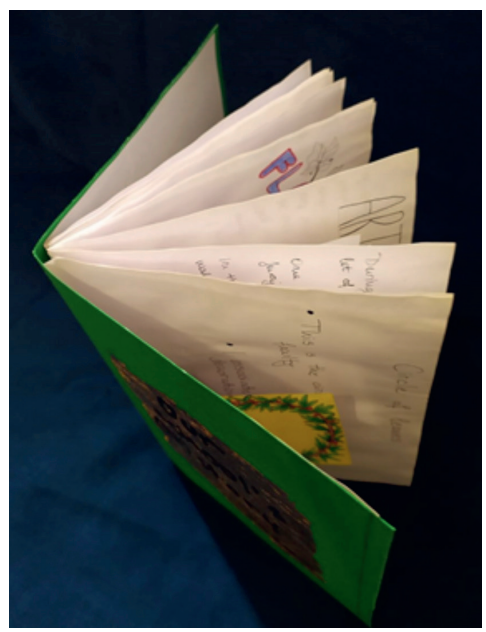

Photograph 2. Finalized pop-up book This Is My School

1 https://web.facebook.com/media/set?set=a.2692918670756811\&type=3 (10.3.2020.) 


\section{CONCLUSION}

To conclude, the possibilities for creative responses are innumerable, both for the students and the teachers, and all you have to do is 'freeing your inner powers' (Osho, 2017, subtitle). Furthermore, in my opinion and following the examples of some educational systems and practices, I would abolish any kind of grading, especially with young learners. Frequently, grades have created frustrations and have been detected as ones of the worst creativity killers. 


\section{REFERENCES}

\section{ELECTRONIC SOURCES:}

1. Cambridge online dictionary. Downloaded on 5 January 2020 from https://dictionary. cambridge. org/dictionary/english/creativity.

2. Dictionary.com. Downloaded on 5 January 2020 from ttps://www.dictionary.com/browse/ creativity? $\mathrm{s}=\mathrm{t}$

3. Merriam-Webster dictionary. Downloaded on 5 January 2020 from https://www.merriamwebster.com/dictionary/creativity

4. Longman dictionary. Visited on 5 January 2020 from https://www.ldoceonline. com/dictionary/ creativity)

5. Youtube, DIY Pop up Scrapbook Album | JK Arts 1346. Downloaded on 17 October 2017 from https://www.youtube.com/watch?v=8Xhy3xEmghQ

6. WikiHow to do anything...How to Make a Pop up Book. Downloaded on 17 October 2017 from https://www.wikihow.com/Make-a-Pop-up-Book

7. The Creative Classroom, Eleven Classroom Creativity Killers, 2015. Visited on 19 February 2020 from http://weblogs.pbspaces.com/creativeclassroom/eleven-classroom-creativity-killers/

8. https://web.facebook.com/media/set?set=a.2692918670756811\&type=3. Created on 10 March 2020.

\section{BOOKS:}

1. Beletić, A. (2017). Interactive Literature, Editorial Caliope, Madrid, Spain: Max Estrella Publishing House.

2. Osho, R. (2017). Kreativnost. Rijeka-Zagreb: Biblioteka Leo, Leo-Commerce d.o.o.

\section{ARTICLES:}

1. Pang, W. (2015). Promoting creativity in the classroom: A generative view. Psychology of Aesthetics, Creativity, and the Arts, 9(2): 122-127. 


\section{KREATIVNOST U ODGOJU I OBRAZOVANJU}

\section{SAŽETAK}

Kreativnost se smatra sposobnošću nadilaženja određenih ustaljenih obrazaca ili pravila i viđenja izvan okvira. Postala je nezamjenjiva kvaliteta u današnjem svijetu koji se brzo mijenja, bilo da je povezana s nekim poduzećem ili odnosom. Kreativni nagon je urođena kvaliteta, koju ipak treba njegovati i prakticirati bilo kod kuće i/ili u obrazovnim ustanovama u što ranijoj dobi. Cilj je ovog rada ponuditi samo mali broj ideja i prijedloga u usporedbi s bezbrojnim kreativnim mogućnostima koje svi učenici i nastavnici mogu imati, odnosno imaju. Nakon što se početna iskra zapali, prepustite ostalo kreativnoj unutarnjoj snazi.

Ključne riječi: transcendiranje obrazaca, (subjektivna) vizualizacija, novi pristupi, sloboda, prijedlozi za kreativno izražavanje, pop-up knjige, ubojice kreativnosti. 